\title{
Figurative Language Used by Characters in the Sherlock Holmes 1 Movie Script "The Study in Pink"
}

\author{
I Gusti Ngurah Agung Yustina ${ }^{1 *}$, Putu Lirishati Soethama ${ }^{2}$ \\ English Department Faculty of Arts - Udayana University \\ 1'[Gunkguzk@gmail.com], ${ }^{2}$ [lirishatinya@yahoo.com] \\ *Corresponding Author
}

\begin{abstract}
The title of this study is Figurative Language Used By Characters in the Sherlock Holmes 1 Movie Script "The Study in Pink". The aims of this study are to discover the types of figurative languages and their meanings used in the movie. The data source was taken from the internet website and this movie script was purely from the Sherlock movie in season one. In collecting data, the method used for this study was documentary method. In analyzing the data, the study used qualitative method. The major theory used is the theory of figurative language proposed by Knickerbocker and Reninger (1963), and the supporting theory about the meaning proposed by Leech (1974). The result shows that there are four types from ten types of figurative language appearing in the movie. In addition, there are three types that are used from seven types of meaning.
\end{abstract}

Key words: Figurative language, Meaning, Character

\section{Abstrak}

Skripsi ini berjudul Bahasa Kiasan yang digunakan oleh Karakter dalam skrip film Sherlock Holmes 1 "The Study in Pink". Tujuan dari penelitian ini adalah untuk menemukan bahasa kiasan yang ditemukan di film ini dan juga menganalisa makna bahasa kiasan yang digunakan. Data ini diambil dari film asli Sherlock Holmes di musim pertama berjudul "The Study in Pink". Dalam pengumpulan data penelitian ini menggunakan metode dokumentasi dan untuk menganalisis data menggunakan metode kualitatif. Teori utama yang digunakan adalah teori bahasa kiasan yang diajukan oleh Knickerbocker and Reninger (1963) dan teori yang mendukung penelitian ini adalah teori makna yang diajukan oleh Leech (1974). Hasil penelitian ini membuktikan bahwa ada empat jenis tipe bahasa kiasan yang ditemukan dari sepuluh tipe yang dikemukakan dan ada tiga tipe makna yang digunakan dari tujuh tipe yang dikemukakan.

Kata kunci: Kiasan, Makna, Karakter

\section{Background of the Study}

Semantics is the branch of linguistics, it is about study of the meaning. Meaning can be described as expression, feeling, and attitude which can be shown by people. They use it to write short story, novel, or poetry, and express their feeling and expression within their literary work. Meaning has wide variation of explanation, because people have different interpretations of the object of the meaning.

$$
\text { Based on Bordwell and }
$$

Thompson (2008: 3) movie is an art form with a language and an aesthetic all its own. In the movie, language is very important. Language is one of the human basic needs and it cannot be separated from their life. As social creature, people need language to communicate and interact with others to fulfill their needs, 
whether verbal or non-verbal. As part of intrinsic element, character is an important aspect because it carries the author's message that can bring various values in human life for instance morality and education.

The movie script "the study in pink" consists of figurative language and meaning. This movie script was purely from the Sherlock movie in season one. It was chosen as the study because it has many figurative expressions.

2. Problems of the Study

a. What types of figurative language are found in the movie script "The Study in Pink"?

b. What meaning of figurative language is used in the movie script "The Study in Pink"?

\section{Aims of the Study}

a. To discover what types of figurative language are found in the movie script "The Study in Pink".

b. To analyze the meaning of figurative language used in the movie script "The Study in Pink".

\section{Research Method}

In this study there are data source, method and technique of collecting data, method and technique of analyzing data

\subsection{Data Source}

Data source refers to the object from which the data were taken. The data used in this writing were taken from the Sherlock Holmes 1 movie script, entitled "The Study in Pink" by Amended. The data source was taken from internet website.

\subsection{Method and Technique of Collecting Data}

In order to get the data from the movie script, the method used for this study was the documentary method. The working procedure consists of several steps. The first step: reading the movie script frequently and intensively to understand the movie script. The second step: identifying and classifying the data from the script to find out the relevant statement in order to find Sherlock Holmes expression. The process was conducted by taking notes from the data related to the study.

\subsection{Method and Technique of Analyzing Data}

In analyzing the data, the study used the qualitative method, in which data were presented and explained based on the theoretical basic figurative language proposed by Knickerbocker and Reninger (1963) and supporting theory about the meaning proposed by Leech (1974). The data taken from the movie script were presented in descriptive way.

\section{Analysis}

\subsection{Types of Figurative Language}

In this section, the study is divided into parts. Every single part presents the analysis of the data beginning with the definition about types of figurative expression which is applied by the characters. Various literary concepts concerning the figurative language have been described. Based on the result of this analysis, it is found four types of figurative language in the movie script "The Study in Pink". They are simile, hyperbole, irony, and allusion.

\subsubsection{Simile}

Simile compares two essentially different objects, actions, or attributes that share some aspects of similarity. Even though simile and metaphor are both forms of comparison, simile allows two ideas to remain distinct in spite of their similarities, whereas metaphor seeks to equate two ideas despite their difference. Simile is introduced by the word 'like' or 'as'. Some examples of 
simile found in the movie script are as follows:

Data 1: The Description of Data, Type of Figurative Language (Scene 69)

\begin{tabular}{l} 
Description of Data \\
SHERLOCK \\
What do you mean, how? Rachel, don't \\
you see? Rachel!! Oh, look at you lot, \\
you're all so vacant! What's it like, not \\
being me, it must be so relaxing. Rachel \\
is not a name. \\
JOHN \\
Then what is it? \\
Sherlock has grabbed his computer, \\
opens his browser. (This is a little \\
laptop - like a notebook, you could \\
shove in a coat pocket.) \\
SHERLOCK \\
John, the luggage label, it had an email \\
address on it. \\
John is straight to the luggage tag. \\
JOHN \\
Jennie dot pink at mephone dot org dot \\
uk. \\
\hline Based on the data above, the word \\
in bold type like in the sentence you're \\
all so vacant! What's it like, not being \\
me, it must be so relaxing is categorized \\
into simile as the type of figurative \\
language. That word is spoken by \\
Sherlock as the participant of the story or \\
the main character to his friend named \\
John as the supporting character. It \\
categorizes into simile because there \\
found a word like. Simile is a stated of \\
comparison introduced by the words -like \\
or -as. It means that sentence has \\
function as a comparison between the \\
sentences: you're so vacant and Sherlock \\
was so relaxing. From the sentence: \\
you're so vacant it means describing the \\
people who are so stupid and they cannot \\
do anything by comparing Sherlock. In \\
this case, Sherlock so relaxes knowing \\
what happen with the killer and the \\
victim.
\end{tabular}

\subsubsection{Hyperbole}

Hyperbole is a figure of an exaggeration used for special effect. It is a figurative language in which statement is exaggerated. It may be used to evoke strong feeling or to create strong impression. It says something which seems large, better, worse or more important than what really is. Some examples are as follows:

Data 2: The Description of Data, Type of Figurative Language (Scene 31)

\begin{tabular}{l} 
Description of Data \\
\hline JOHN \\
I'd say you were a private detective but \\
SHERLOCK \\
But? \\
JOHN \\
The police don't go to private \\
detectives. \\
SHERLOCK \\
I'm a consulting detective. Only one in \\
the world, I invented the job.
\end{tabular}

Based on the data above, the word in bold type only one in the clause only one in the world, I invented the job is categorized into hyperbole as the type of figurative language. That word is spoken by Sherlock as the participant of the story or the main character to his friend named John as the supporting character. The scene was happen in the cab, when they went the crime scene. In the cab they talked about what the Sherlock's job. From the data above categorize as hyperbole because it gives more effect to the readers and to his friend, John. It means that Sherlock's expression is an overstatement to impress John and make him pays attention to what Sherlock had said. The bold type above is a hyperbole because it can be seen from the supporting sentence Who are you? What do you do? means John asked Sherlock about his job. And another supporting sentence I'd say you were a private 
detective but-- means John does not believe Sherlock is a private detective. The bold type above means he wanted to assert that he was the only one who had such a job. In this script there was just ordinary detective is named Lestrade. But in this case Sherlock said he is only one invented this job. The bold type above can be supporting from the clause in the world means only he did the job in the world. But in real life there were many person invented that job, not only one.

\subsubsection{Irony}

Irony is the recognition of the incongruity, or differences between reality and appearance. It is also a form of sarcasm, which is the opposite of the literal meaning of the word or phrase intended.

Data 3: The Description of Data, Type of Figurative Language (Scene 53)

\begin{tabular}{l}
\hline \multicolumn{1}{c}{ Description of Data } \\
\hline SHERLOCK \\
It had to be pink. Obviously. \\
JOHN \\
Why didn't I think of that? \\
SHERLOCK \\
Because you're an idiot. \\
On John: stung by this. \\
SHERLOCK \\
Don't look like that - practically \\
everyone is.
\end{tabular}

Based on the data above, the word in bold type idiot in the clause because you are an idiot is categorized into irony as the type of figurative language. That word is spoken by Sherlock as the participant of the story or the main character to his friend named John as the supporting character. According to Oxford Advanced Learner's Dictionary' the word idiot literally means a very foolish person. It is an irony because it can be seen from the supporting sentence Why didn't I think of that? that means
John's statement looks to be different from Sherlock about color of the pink of the suitcase. And another supporting sentence Don't look like that - practically everyone is." means Sherlock's expression is sarcastic to John by humiliating John. But the word idiot meaning very stupid is apposite to the real or literal meaning. In fact John was not idiot. He is a clever person because in the story he is a doctor from military service in Afghanistan. So, that's why Sherlock's expression to John, his friend, is considered to be irony.

\subsubsection{Allusion}

Allusion is a reference to some well-known place, event, or person. Not a comparison in the exact sense, but a figure in the sense that it implies more than its narrow meaning. Some examples of allusion are as follows:

Data 4: The Description of Data, Type of Figurative Language (Scene 17)

\begin{tabular}{l} 
Description of Data \\
\hline JOHN \\
I think I got shot. \\
As they settle at a table... \\
JOHN \\
You're still at Barts then? \\
MIKE \\
Teaching now - bright young things, \\
like we used to be. God, I hate them. \\
What about you? Staying in town till \\
you get yourself sorted? \\
JOHN \\
(Shakes head) \\
Can't afford London on an army \\
pension. \\
MIKE \\
And you couldn't bear to be anywhere \\
else. Not the John Watson I know! \\
\hline Based on the data above, the word \\
in bold type London in the clause Can't \\
afford London on an army pension is \\
categorized into allusion as the type of
\end{tabular}


figurative language, because it mention the name of a well-known as city. That word is spoken by John as the participant of the story and his friend named Mike as the supporting character. London is the capital and the most populous city of the United States. London is a leading global city in the commerce, art, finance, fashion, tourist, and many more. London is the world's largest financial centre and cultural capital; it is the world's most visited city as measured by international arrivals. It means that is quite makes sense that sentence is include as allusion. In addition, there is supporting sentence Can't afford London on an army pension in this script. It means life in the London must be have a job or more money to live in the capital of England. In this case, the John wants to express his problem to his friend.

\subsection{Types of Meaning of Figurative Language}

The theory used to analyze the meaning of figurative language in the movie script "The Study In Pink" is proposed by Leech (1974). There are three types of meaning in figurative expression used in this movie script. They are social meaning, affective meaning, and reflected meaning.

\subsubsection{Social Meaning}

Social meaning is the meaning conveyed by the piece of language about the social context of its use. It is related to the situation in which an utterance is used. The illocutionary force of an utterance can also have social meaning. According to the social situation, a sentence may be uttered as request, an apology, a warning or a threat. Some examples of social meaning are as follows:
Data 5: The Meaning of Figurative Language (Scene 28)

\begin{tabular}{l}
\hline \multicolumn{1}{c}{ Description of Data } \\
\hline They look at each other. Oh! \\
JOHN \\
That's a skull \\
SHERLOCK \\
Friend of mine. Well I say friend... \\
Mrs. Hudson comes bustling in. \\
MRS. HUDSON \\
What do you think, Dr. Watson -there's \\
another bedroom upstairs. \\
(Knowing look) \\
If you'll be needing two bedrooms \\
John looks at her, a little affronted. \\
\hline
\end{tabular}
Based on the data above, the word in bold type friend in the clause Friend of mine. Well I say friend is categorized into social meaning as the type of meaning. That word is spoken by Sherlock as the participant of the story or the main character to his friend named John as the supporting character. The scene was happen in the Sherlock's room. When John went to Sherlock's house to be a flat mate, he got attraction to the skull in front of him. So, he asked Sherlock about that skull. The bold type above categorizes into social meaning in the illocutionary force, it is about assertion. Assertion means to reflect the personal feeling of the Sherlock and to give statement. When John as him about the skull in his house, Sherlock said Well I say friend..., it has deep meaning addressed to John that is about requesting a friend, because Sherlock does not have friend in his house. It is not about the real skull, but it is about the friendship.

\subsubsection{Affective Meaning}

Affective meaning is a sort of meaning which can reflect the personal feeling of the speaker, including his attitude to the listener, or his attitude to something he is talking about. This 
meaning can be clearly conveyed simply by the choice of the right words as many emotive contents in themselves. The next paragraph exemplifies the use of affective meaning:

Data 6: The Meaning of Figurative Language (Scene 56)

\begin{tabular}{l}
\hline \multicolumn{1}{c}{ Description of Data } \\
\hline SHERLOCK \\
How do you feel about the violin? \\
JOHN \\
I'm sorry, what? \\
SHERLOCK \\
I play the violin when I'm thinking, and \\
sometimes I don' talk for days on end - \\
would that bother you? Potential flat \\
mates should know the worst about each \\
other. \\
John, flummoxed - looks to Mike. \\
JOHN \\
Oh! You told him about me? \\
Mike has been watching this with a \\
knowing air. Enjoying the routine
\end{tabular}

Based on the data above, the word in bold type end in the sentence I play the violin when I'm thinking, and sometimes I don' talk for days on end - would that bother you is categorized into affective meaning as the type of meaning. That word is spoken by Sherlock as the participant of the story or the main character to his friend named John as the supporting character. According to Oxford Advanced Learner's Dictionary the word end literally means an extreme point of thing; the furthest or last part of things. It is an irony because it can be seen from the supporting sentence would that bother you? Potential flat mates should know the worst about each other means Sherlock wants to John accept his worst to be flat mate and become his friend. And another supporting sentence sometimes I don' talk for days on end means Sherlock cannot talk in a day. In fact Sherlock wants to express his emotion to John. It likes Sherlock did not want someone bothering him when he was focused on his case and when he was thinking.

\subsubsection{Reflected Meaning}

Reflected meaning involves an interconnection on the lexical level of language; it is the meaning, which arises in case of multiple conceptual meaning, when one sense of word forms part of our response to another sense. The reason why the sentence is included as having reflected meaning as the sentence contains two words that always compares one sense with a different point of view.

Data 7: The Meaning of Figurative Language (Scene 36)

\begin{tabular}{l} 
Description of Data \\
\hline$\ldots$ \\
JOHN \\
(A whisper - can't hear) \\
What am I doing here? \\
SHERLOCK \\
(Also a whisper) \\
Helping me make a point. \\
He flicks his eyes at Lestrade. \\
JOHN \\
I'm supposed to be helping you pay the \\
rent! \\
SHERLOCK \\
Yeah, this is more fun. \\
JOHN \\
Fun?? There is a woman lying dead! \\
SHERLOCK \\
Perfectly sound analysis, but I was \\
hoping you'd go deeper. On John: \\
stung! Then he gets to work. Bends over \\
her, sniffs her mouth. \\
Based on the data above, the word \\
in bold type fun in the clause this is more \\
fun is categorized into reflected meaning \\
as the type of meaning. That word is \\
spoken by Sherlock as the participant of \\
the story or the main character to his \\
friend named John as the supporting
\end{tabular}


character. According to Oxford Advanced Learner's Dictionary the word fun literally means amusing; providing pleasure or enjoyable activities. It is a reflected because it can be seen from the supporting sentence Fun?? There is a woman lying dead means in John's point of view, he is not expected about what Sherlock said about the dead woman, it is fun to Sherlock. John likes paying attention with the dead woman. And another supporting sentence this is more fun means in the Sherlock's point of view, the dead woman is so fun. In this case John did not want to playing game with the victim. However, Sherlock was happy with the victim.

\section{Conclusion}

The result shows that there are four types used from ten types of figurative language which appear in the movie. Those types are simile, hyperbole, irony, and allusion. In addition, there are three types used from seven types of meaning. Those types are social meaning, affective meaning, and reflected meaning.

\section{Reference}

Amended, G. 2010. A Study in Pink Shooting Script. England. Resource:

http://downloads.bbc.co.uk/writersr oom/scripts/Sherlock-A-Study-inPink-final-shooting-script.pdf.

Bordwell and Thompson. 2003. An Introduction Film and Art. New York: University of Wisconsin.

Knickerbocker, K. L. and W. Reninger. 1963. Interpreting Literature. New York : Holt, Rinehart and Winston.
Leech, G. N. 1974. Semantics; Study of Meaning (second edition). Auxland: Penguin Books.

Nusawan. P. 2017. Figurative Language in Roth's “Allegiant". Denpasar: Undergraduate Thesis, English Department, Faculty of Art, Udayana University.

. 1995. Oxford Advanced Leaner's Dictionary (Fifth Edition). Great Britain: Oxford University Press. 